\title{
Studies on Supplementation of Natural Ascorbic Acid in Dried Aonla (Emblica officinalis Gaertn) Powder
}

\author{
Shiv Kant Tripathi ${ }^{*}$, Suryamani Kumar ${ }^{2}$ and Prasanna Kumar Bisoi ${ }^{3}$ \\ ${ }^{1}$ Harcourt Butler Technological Institute, Kanpur, India \\ ${ }^{2}$ Sanjay Gandhi Institute of Dairy Technology, Patna, India \\ ${ }^{3}$ Orissa University of Agriculture \& Technology, Bhubaneswar, India \\ *Corresponding author
}

\section{A B S T R A C T}

\begin{tabular}{|l||}
\hline K e y w o r d s \\
Aonla, Aonla \\
powder, Drying, \\
$\begin{array}{l}\text { Supplementation, } \\
\text { Ascorbic acid }\end{array}$ \\
\hline Article Info \\
\hline $\begin{array}{l}\text { Accepted: } \\
\text { 07 August } 2020 \\
\text { Available Online: } \\
\text { 10 September } 2020\end{array}$ \\
\hline
\end{tabular}

Fruit and fruit products both are an important supplement to the human diet as they provide almost all the vital components required for normal growth and development of the human body leading to the healthy physique and mind. Aonla is a very rich source of ascorbic acid. Its ascorbic acid lost during the process of drying. Therefore, supplementation with fresh aonla juice in aonla powder is one of the essential treatments to make its more nutritive and enriched. Aonla powder were taken into four cleaned petri dishes and marked as A (control), B, C and D further, it was supplemented with ascorbic acid 5, 10 and 15 times to samples of petri dish B, C and D, respectively. The present research revealed that marginal differences in ascorbic acid contents were observed in various treatments. The maximum retention of ascorbic acid with petri dish B samples and decreasing with increasing of treatments that means the minimum retention in sample of petri dish D. Treated samples had higher ascorbic acid content with respect to the control samples (petri dish A).

\section{Introduction}

Aonla (Emblica officinalis Gaertn), the king of arid fruits, popularly known as Indian gooseberry, is an important fruit crop of tropical and subtropical region of India. India ranks first in the world in aonla area and production volume. It is considered to be a "wonder fruit for health". Aonla is highly nutritious and important dietary sources of vitamin $\mathrm{C}$ (Ascorbic acid), minerals and amino acids. It also contains tannins, phyllembelic acid, phyllemblin, rutin, curcuminoides, emblicol and phenolic compounds (Zhang et al., 2000). Nutritional losses of aonla fruits is major problem due to plucking, transportation, pre-processing treatment during conversion of aonla fruits into different food products. There are reports that $25-93 \%$ losses occur in vitamin $\mathrm{C}$ and other nutrients during processing of aonla into preserve (Sethi and Anand, 1983; Kalra et al., 1988; Tandon et al., 2003). Raw aonla fruits, being highly acidic and astringent in taste, are unacceptable to consumers. Therefore, they are generally processed to sugar-rich products 
such as preserves, candies, etc (Kalra, 1988). Aonla fruits are commonly used for processing like Aonla pulp, Jam, Syrups, Morrabba, Squash, Chutney, Candy, Toffee, Pickles, Aonla sweet, Dehydrated aonla and aonla Powder. Preservation of foodstuffs through dehydration is an ancient practice. Aonla powder is one of the dried forms of aonla fruits, but its nutritional quality (Ascorbic acid) is not retained as in fresh aonla fruits due to processing (Pareek and Kaushik, 2012). The fruit contains a chemical substance called leucanthocyanin which retards the oxidation of Ascorbic acid (Balaji and Prasad, 2014). The fresh fruit of aonla are very rich source of Ascorbic acid (500-1500 $\mathrm{mg} / 100 \mathrm{~g}$ ) and used as a strong rejuvenator in Indian pharmacopoeia (Pathak and Ram, 2007). It is also appreciable source of total sugar $\quad(7.53 \mathrm{mg} / 100 \mathrm{~g})$, calcium (14.91 $\mathrm{mg} / 100 \mathrm{~g})$, iron $(0.62 \mathrm{mg} / 100 \mathrm{~g})$ and phosphorus $(11.81 \mathrm{mg} / 100 \mathrm{~g})$ and also has great potential for processing (Dachiya and Dhawan, 2001). Supplementation with fresh aonla juice in aonla powder is one of the essential treatments to make its more nutritive and enriched.

\section{Materials and Methods}

The procurement of aonla fruits were done in the first week of February. These aonla fruits were obtained from local garden of C.S.A University, Kanpur (U.P).

\section{Grading, cleaning and washing}

The aonla fruits were graded on the basis of their maturity and size. These aonla fruits were initially washed by plenty of tap water to remove adherent undesirable extraneous matter. The ascorbic acid was determined by 2, 6-dichlorophenol-indophenol visualtitration method as suggested by Palmer (1993).

\section{Pre-processing treatments}

Aonla fruits are highly acidic in nature and bitter in taste, so these are consumed after some pre-processing treatments. Blanching and drying are most important pre-processing treatments in the production of aonla powder.

\section{Blanching of aonla fruits}

The special heat treatment to inactivate enzymes is known as blanching. It is one of the essential treatments in the preparation of aonla fruit for dehydration. The treatment of blanching commonly involves by means of some heat, usually either steam or boiling water. The combination of time and temperature used depend on the final processing to be employed as well as on the nature of materials to be processed. The treatment of blanching is advantageous in the removal of tissue gas, shrinking and heating of materials, inactivation of enzyme particularly catlase and peroxidase present in the tissue. Enzyme inactivation in the material to be dehydrated is important because again no further cooking previous to storage is involved in the process.

$5 \mathrm{~kg}$ of aonla fruit were taken separately in two equal lots and these lots were blanched in boiling water for 10 minutes. The blanched aonla fruits were cut into small pieces with the help of sharp edge stainless steel blade and seeds were removed from the fruits. Weight of blanched aonla flakes and seeds were taken by weighing machine.

\section{Drying of flaked aonla fruits}

Aonla fruits are highly perishable in nature as its storage in atmospheric conditions after harvesting is very limited (Kumar and Nath, 1993). Storage facilities such as cold storage, controlled/modified atmospheric storage, being very expensive are not direct reach of 
poor farmers. Preservation of food stuffs through dehydration is an ancient practice. The modern method of dehydration i.e. drying fruits and vegetables under controlled conditions of temperature and humidity assumed importance as major industry on account their concentrated form, low cost, convenience and easy transportability with increase shelf life, dried fruits and vegetables product and also other dehydrated fruits have become more popular (Lal et al., 1986). Pretreated (blanched) flakes of aonla fruit were dried in digital oven at $65^{\circ} \mathrm{C}$ till the weight was constant as suggested by Pareek and Kaushik (2012).

\section{Grinding of dried aonla flakes}

Dried aonla flakes were converted into aonla powder by grinding with the help of grinder. This aonla powder was stored in cleaned glass jar and determined ascorbic acid content. Further, $20 \mathrm{gm}$ of aonla powder were taken into each four cleaned petri dishes and marked as A, B, C and D. Petri dish A was considered as a control (untreated) sample, which was kept in desiccators.

\section{Supplementation of aonla powder with ascorbic acid}

Aonla juice was extracted by juice extractor. This aonla juice was filtered through muslin cloth and transferred into glass jar. Further, determined ascorbic acid content of aonla juice and stored at refrigerated temperature $\left(2^{\circ} \mathrm{C}\right)$. Further, aonla juice was taken into pipette and sprinkled over the aonla powder of petri dish B, C, and D for supplementation of ascorbic acid until the stage of saturation was reached. These ascorbic acid treated aonla powder petri dishes were kept in digital oven for drying at $40^{\circ} \mathrm{C}$ for 8 hours. After drying, large and hard granules were formed in aonla powder. These aonla powder were grinded to make again small granules powder.
Similarly, this process was repeated 5 times for petri dish B, 10 times for petri dish C, and 15 times for petri dish D. After supplementation and drying, ascorbic acid content of enriched aonla powder in petri dish $\mathrm{B}, \mathrm{C}$, and $\mathrm{D}$ were determined.

\section{Results and Discussion}

The present investigation has been under taken to know exactly how much ascorbic acid increased and retained in the dried aonla powder. The data of Table 1 show that the blanching does not significantly affect the ascorbic acid content of dried aonla product. The ascorbic acid content of $280 \mathrm{mg} / 100 \mathrm{~g}$ was recorded in dried aonla product. Similar findings were observed by Shrivastava and Kumar (2007) and Singh et al (2006). It may be due to inactivation of oxidase enzyme (Prajapati et al., 2011).

Table 2 illustrated the effect of supplementation treatments of ascorbic acid on dried aonla powder. It is clearly shown in Table 2 that after 5 treatments of supplementation in samples of petri dish B followed by drying; capability of absorption of juice by powder was found to be decreased from $7 \mathrm{ml}$ to $5.5 \mathrm{ml}$. The supplementation of ascorbic acid was found maximum (85.95 \pm $0.04 \mathrm{mg}$ ) in first two treatments as compared to later treatments. The overall supplementation of ascorbic acid in petri dish B was $666.76 \mathrm{mg}$ against initial value of 280 mg per 100 gm powder. Further, drying of the sample only $500 \pm 0.10 \mathrm{mg}$ ascorbic acid was retained in aonla powder while $166.76 \mathrm{mg}$ ascorbic acid was lost during drying process.

It is also shown in Table 2 that on further supplementation of powder by aonla juice up to 10 times in petri dish $\mathrm{C}$, the absorption capability of powder sample was further decreased to $4.5 \mathrm{ml}$. 
Table.1 Enrichment of dried aonla powder with fresh aonla juice

\begin{tabular}{|c|c|c|c|c|}
\hline Characteristics & Petri dish A & Petri dish B & Petri dish $\mathrm{C}$ & Petri dish D \\
\hline No. of Treatment (times) & Control (no treatment) & 5 & 10 & 15 \\
\hline Initial weight of aonla powder (gm) & 20 & 20 & 20 & 20 \\
\hline $\begin{array}{l}\text { Final weight of aonla powder (gm) } \\
\text { (after supplementation) }\end{array}$ & 20 & $24.5 \pm 0.12$ & $27.8 \pm 0.14$ & $29.8 \pm 0.16$ \\
\hline $\begin{array}{l}\text { Initial ascorbic acid content (mg) (per } 100 \mathrm{gm} \text { of } \\
\text { aonla powder) }\end{array}$ & $280 \pm 0.08$ & $280 \pm 0.08$ & $280 \pm 0.08$ & $280 \pm 0.08$ \\
\hline Total supplemented ascorbic content (mg) & 280 & 666.76 & 967.56 & 1207 \\
\hline $\begin{array}{l}\text { Retention of ascorbic acid content (mg) (per } 100 \\
\text { gm of aonla powder) }\end{array}$ & $280 \pm 0.08$ & $500 \pm 0.10$ & $600 \pm 0.09$ & $630 \pm 0.12$ \\
\hline $\begin{array}{l}\text { Losses of ascorbic acid (mg) } \\
\text { (per } 100 \text { gm of aonla powder) }\end{array}$ & 0 & 166.76 & 367.57 & 577.00 \\
\hline
\end{tabular}

Values are of mean \pm SD of three replicates

Aonla juice contains $1227.8 \mathrm{mg} / 100 \mathrm{gm}$ of Ascorbic acid used for treatments

Table.2 Effect of supplementation treatment on dried aonla powder with natural ascorbic acid (aonla juice)

\begin{tabular}{|c|c|c|c|c|c|c|c|c|c|c|c|c|c|c|c|c|}
\hline \multirow[t]{2}{*}{ Characteristics } & \multicolumn{15}{|c|}{ No. of Treatment } & \multirow{2}{*}{$\begin{array}{l}\text { Total } \\
\text { value }\end{array}$} \\
\hline & $\mathbf{I}$ & II & III & IV & $\mathbf{V}$ & VI & VII & VIII & IX & $\mathbf{X}$ & XI & XII & XIII & XIV & XV & \\
\hline \multicolumn{17}{|l|}{ Petridish A (Control) } \\
\hline \multicolumn{17}{|l|}{ Petridish B } \\
\hline Aonla juice (ml) & 7 & 7 & 6 & 6 & 5.5 & & & & & & & & & & & 31.5 \\
\hline $\begin{array}{l}\text { Ascorbic acid (mg) } \\
\text { (per 100gm) }\end{array}$ & $85.95 \pm 0.04$ & $85.95 \pm 0.03$ & $\begin{array}{c}73.67 \pm 0 \\
03\end{array}$ & $\begin{array}{l}73.67 \\
\pm 0.02\end{array}$ & $\begin{array}{l}67.53 \\
\pm 0.04\end{array}$ & & & & & & & & & & & 666.76 \\
\hline \multicolumn{17}{|l|}{ Petridish C } \\
\hline Aonla juice (ml) & 7 & 7 & 6 & 6 & 5.5 & 5 & 5 & 5 & 5 & 4.5 & & & & & & 56 \\
\hline $\begin{array}{l}\text { Ascorbic acid (mg) } \\
\text { (per 100gm) }\end{array}$ & $85.95 \pm 0.04$ & $85.95 \pm 0.03$ & $\begin{array}{c}73.67 \pm 0 \\
03\end{array}$ & $\begin{array}{l}73.67 \\
\pm 0.02\end{array}$ & $\begin{array}{l}67.53 \\
\pm 0.04\end{array}$ & $\begin{array}{l}61.39 \\
\pm 0.05\end{array}$ & $\begin{array}{l}61.39 \\
\pm 0.04\end{array}$ & $\begin{array}{l}61.39 \\
\pm 0.03\end{array}$ & $\begin{array}{l}61.39 \\
\pm 0.04\end{array}$ & $\begin{array}{l}55.25 \pm 0 \\
05\end{array}$ & & & & & & 967.56 \\
\hline \multicolumn{17}{|l|}{ Petridish D } \\
\hline Aonla juice (ml) & 7 & 7 & 6 & 6 & 5.5 & 5 & 5 & 5 & 5 & 4.5 & 4.5 & 4.5 & 4 & 3.5 & 3 & 75.5 \\
\hline $\begin{array}{l}\text { Ascorbic acid (mg) } \\
\text { (per 100gm) }\end{array}$ & $85.95 \pm 0.04$ & $85.95 \pm 0.03$ & $\begin{array}{c}73.67 \pm 0 \\
03\end{array}$ & $\begin{array}{l}73.67 \\
\pm 0.02\end{array}$ & $\begin{array}{l}67.53 \\
\pm 0.04\end{array}$ & $\begin{array}{l}61.39 \\
\pm 0.05\end{array}$ & $\begin{array}{l}61.39 \\
\pm 0.04\end{array}$ & $\begin{array}{l}61.39 \\
\pm 0.03\end{array}$ & $\begin{array}{l}61.39 \\
\pm 0.04\end{array}$ & $\begin{array}{l}55.25 \pm 0 \\
05\end{array}$ & $\begin{array}{l}55.25 \\
\pm 0.05\end{array}$ & $\begin{array}{c}55.25 \pm \\
0.03\end{array}$ & $\begin{array}{l}49.12 \\
\pm 0.04\end{array}$ & $\begin{array}{l}42.97 \\
\pm 0.03\end{array}$ & $\begin{array}{c}36.8 \\
3 \pm 0 \\
.01\end{array}$ & 1207 \\
\hline
\end{tabular}

Values of ascorbic acid are mean $\pm \mathrm{SD}$ of three replicates

Aonla juice contains $1227.8 \mathrm{mg} / 100 \mathrm{gm}$ of Ascorbic acid used for treatments 
Table.3 Yield of aonla powder

\begin{tabular}{|l|c|}
\hline Total weight of aonla fruit (kg) & $\mathbf{5 . 0}$ \\
\hline Weight after blanching (kg) & 4.54 \\
\hline Weight of edible flesh (kg) & 4.22 \\
\hline Weight of stones (kg) & 0.32 \\
\hline Weight of aonla powder (kg) & 0.68 \\
\hline Dehydration Ratio & $6.2: 1$ \\
\hline Yield of powder (\%) & 13.60 \\
\hline
\end{tabular}

The supplementation of ascorbic acid was found maximum $(61.39 \pm 0.05 \mathrm{mg})$ in $6^{\text {th }}$ to $9^{\text {th }}$ treatments but decreased in $10^{\text {th }}$ treatment $(55.25 \pm 0.05 \mathrm{mg})$. The overall supplementation of ascorbic acid in petri dish C was $967.56 \mathrm{mg}$ while retains only $600 \pm$ $0.09 \mathrm{mg}$ of ascorbic acid. The samples of petri dish $\mathrm{C}$ gained only $100 \mathrm{mg}$ ascorbic acid in comparison to samples of petri dish B (Table 1). Similarly, the absorption capability of samples of petri dish D was further decreased to $3 \mathrm{ml}$ (Table 2). The overall supplementation of ascorbic acid in petri dish D was $1207 \mathrm{mg}$ (total $75.5 \mathrm{ml}$ of aonla juice) while retains only $630 \pm 0.12 \mathrm{mg}$ of ascorbic acid. The increase in ascorbic acid content in sample D was insignificant $(30 \mathrm{mg})$ with respect to ascorbic acid gained in sample $\mathrm{C}$ (Table 1).

It is clearly shown in Table 1 that the maximum and minimum absorption and retention of ascorbic acid was found in sample of petri dish B and petri dish D, respectively. However, the ascorbic acid retention in petri dish A was $500 \pm 0.10 \mathrm{mg}$ after supplementation of $666.76 \mathrm{mg}$ ascorbic acid but in case of petri dish $\mathrm{C}$ and $\mathrm{D}$ the value was $600 \pm 0.09$ and $630 \pm 0.12$ after supplementation of 967.56 and $1207 \mathrm{mg}$ ascorbic acid, respectively. This may be due to the repeatedly heating of product which affects the retention capacity of ascorbic acid.
Pareek and Kaushik (2012) and Prajapati et al., (2011) also reported that drying method and degree of heating affects the retention of ascorbic acid in dried aonla products. The final product (aonla powder) was obtained $0.68 \mathrm{~kg}$ made from $5.0 \mathrm{~kg}$ of fresh Aonla fruit. The yield of aonla powder was $13.60 \%$ with dehydration ratio is about 6.2:1 (Table 3).

In conclusions the present research revealed that marginal differences in ascorbic acid contents were observed in various treatments. The result of the first treatment of aonla powder supplementation with fresh juice followed by drying is much encouraging. But, further supplementation of powder with aonla juice to 10 and 15 times, the absorption capability was decreased to 4.5 and $3 \mathrm{ml}$, respectively and ascorbic acid losses also increased with increasing number of treatments. Therefore, it can be concluded that the vital value of powder is much more enhanced in initial treatments as compared to later treatments. All treated samples had higher ascorbic acid content with respect to the control samples.

\section{References}

Balaji, V., Prasad, V.M. (2014). Studies on value added kinnow - aonla blended ready to serve beverage. J. Food 
Process Technol., 5: 288.

Dachiya, S.P. and Dhawan, S.S. (2001). Physico-chemical characteristics of aonla (Emblica officinalis Gaertn) chakaiya. Indian Food Packer, 55: 133.

Kalra, C. L (1988). The chemistry and technology of aonla (Phyllanthus emblica linn), Indian Food Packer, 42(4):67-82.

Kumar, S. and Nath, V. (1993). Storage stability of amla fruits: a comparative study of zero-energy cool chamber versus room temperature. J. Food Sci. Technol., 30(3), 202-203.

Lal, G., Siddappa, G.S. and Tandon, G.L. (1986). Drying of fruits and vegetables. Indian Council of Agricultural Research, New Delhi.

Palmer, F.J. (1993). Fruit Juice and Soft drink. In: Food Industries Manual (Ed: Christopher G.J. Baker, M.D. Ranken, R.C. Kill), Blackie Academic and Professional, UK (Pp235).

Pareek, S. and Kaushik, R.A. (2012). Effect of drying methods on quality of Indian gooseberry (Emblica officinalis Gaertn.) powder during storage. J. Sci. Industrial Res., 71 (11): 727-732.

Pathak, R.K. and Ram, R.A. (2007). Organic production of aonla. In: National seminar on "Recent advances in production, protection and post harvest management of grape, mandarin and arid fruits". College of Horticulture, Mandsaur, pp 133-136, March 17-18.

Prajapati, V.K., Nema, P.K. and Rathore, S.S. (2011). Effect of pretreatment and drying methods on quality of valueadded dried aonla (Emblica officinalis Gaertn) shreds. J. Food Sci. Technol., 48(1):45-52

Sethi, V. and Anand, J.C. (1983). Retention of nutrients in carrot and amla preserve. Indian Food Packer, 37(6): 64-67.

Shrivastava, R.P. and Kumar, S. (2007) Fruit and vegetable preservation: principles and practices. International Book Distributing Co., Lucknow, p 146

Singh, R., Dashora, L.K. and Upadhyay, B. (2006). Effect of pre-drying treatments and drying methods on physiconutritional quality of dehydrated aonla shreds. Indian Food Packer, 60(3):5763.

Tandon, D.K., Yadav, R.C., Sood, S., Kumar, S. and Dikshit, A. (2003). Effect of blanching and lye peeling on the quality of aonla candy. Indian Food Packer, 57: 147-152.

Zhang, Y.J., Tanaka, T, Iwamoto, Y., Yang, C.R. and Kouno, I. (2000). Novel norsesquiterpenoids from the roots of Phyllanthus emblica. J. Nat. Prod. 63(11): 1507-1510.

\section{How to cite this article:}

Shiv Kant Tripathi, Suryamani Kumar and Prasanna Kumar Bisoi. 2020. Studies on Supplementation of Natural Ascorbic Acid in Dried Aonla (Emblica officinalis Gaertn) Powder. Int.J.Curr.Microbiol.App.Sci. 9(09): 578-583. doi: https://doi.org/10.20546/ijcmas.2020.909.073 